Federal Reserve Bank of Minneapolis

Research Department

\title{
DEBT FINANCING OF DEPOSIT INSURANCE PAYMENTS: A POLICY CHOICE OF REAL IMPORT
}

Preston J. Miller and Richard M. Todd*

Working Paper 494

May 1992

\begin{abstract}
This paper investigates the macroeconomic and welfare effects of a particular public finance decision. That decision was to use debt rather than current taxation to finance deposit insurance payments related to the savings and loan debacle. We find that this decision could have significantly raised real interest rates and affected welfare. The analysis is conducted in a dynamic, open-economy, monetary general equilibrium model in which parameters are set based on empirical observations.
\end{abstract}

*Both, Federal Reserve Bank of Minneapolis.

The views expressed herein are those of the authors and not necessarily those of the Federal Reserve Bank of Minneapolis or the Federal Reserve System. 
In present value terms, deposit insurance payments stemming from the savings and loan debacle are estimated to total roughly $\$ 215$ billion in 1990 dollars. ${ }^{\$}$ The majority of the payments can be considered a transfer to depositors financed by debt issue. Our research suggests that the choice of debt financing rather than current taxation led to appreciably higher real interest rates and a somewhat higher real value of the dollar. The debt financing, accompanied by a nonaccommodating monetary policy, benefitted current and future savers in the U.S. and current producers of traded goods and future savers in the rest of the world. But it hurt all other agents-current and future, home and abroad. Our analysis attempts to explain and crudely quantify these effects.

We focus on just the public finance aspect of the deposit insurance program. In order to describe our policy investigation, we first summarize the nature of deposit insurance payments using an example. With that as background, we then motivate our research focus.

The example describes a typical Resolution Trust Corporation (RTC) intervention:

The RTC takes over an insolvent savings and loan with insured deposit liabilities of $\$ 1$ billion and assets in real estate worth $\$ 700$ million. The RTC immediately pays the $\$ 1$ billion to insured depositors and finances the payments by issuing debt. The RTC manages and maintains the properties acquired in the assumption for a number of years before being able to sell them for an amount with present value of $\$ 700$ million.

The typical intervention, thus, can be divided into these three main components:

1. An exchange of assets. The RTC pays out $\$ 700$ million and receives $\$ 700$ million in properties.

2. Management and maintenance expenses. The RTC expends resources, for example, to collect rents and make repairs.

3. A transfer financed by debt issue. The RTC pays out $\$ 300$ million to depositors above what it acquires in properties and finances the payments by issuing debt. 
The transfer component generates the largest net outlay. Because of the lapse of time between the RTC's acquiring and selling of assets, the first component - the $\$ 700$ million in the example-initially shows up in the budget as an expenditure when depositors are paid and later as a receipt when the assets are sold. Over time, however, these expenditures and receipts net out. So, the estimate of $\$ 215$ billion for the cost of the deposit insurance resolution is the cost for management and maintenance of properties plus the cost of the transfers. Based on CBO estimates those costs are split roughly one-fourth and three-fourths respectively, or $\$ 55$ billion for management and maintenance and $\$ 160$ billion for transfers.

We investigate whether the debt financing of the transfer component has had significant real effects. We ignore the other two components because we believe their economic impact to be small. Asset exchanges generally should have virtually no effect on the economy. ${ }^{2}$ Moreover, in this case they are eventually reversed. Government spending on management and maintenance of properties also should have little or no economic impact. In this case they essentially substitute for private spending.

Some have questioned whether even the transfer component of deposit insurance payments matters. ${ }^{3}$ However, our focus is on the financing of the transfers, not on the transfers themselves. We argue that the decision to use debt financing rather than current taxation has mattered. The issue is basically about Ricardian equivalence.

Our argument that the choice to use debt financing has mattered is based on a model in which Ricardian equivalence is not a good approximation. The structure of our model implies that debt financing has had real effects. However, the structure doesn't determine how large those effects may have been. Thus, we parameterize the model based on empirical observations to gain insights into the likely magnitudes of various effects and their relative importance in terms of how they affect welfare. 
We conduct our analysis using a dynamic, general equilibrium model. The motivation for our model is similar to that used by Auerbach and Kotlikoff $(\mathrm{AK}, 1987)$ for their model. Like AK, we wanted a dynamic model, because alternative financing policies involve different levels of tax revenues over time. Like them, we wanted a general equilibrium model to give an economic structure that is invariant to the policy interventions we consider and to allow us to measure welfare effects from different policies. And, like them, we conduct our analysis in an overlapping generations model which can be applied to many policy questions rather than in a model constructed to answer the specific question at hand.

With all the similarities between $\mathrm{AK}$ and us, it seems natural to ask why we simply didn't use their model. Our answer is that our model provides some interesting new perspectives about the transmission of policy effects. Our model has both advantages and disadvantages relative to the AK model. It refines the AK model along some dimensions, while being coarser than it along some others.

For this study our model has four major advantages over the AK model. First, unlike AK ours has intragenerational borrowing and lending. We believe this is important for analyzing default on private debt and the welfare effects of deposit insurance financing for agents on opposite sides of the debt market. Second, while AK has no money, ours has separate monetary and budget policies, and our analysis suggests the response of monetary policy is crucial in determining the effects of government financing decisions on real interest rates and prices. Third, we assume an open economy with a world capital market, which seems to be a more accurate description of the world in which we live. It implies that an increase in domestic borrowing will have a smaller effect on real interest rates than in the AK model, since savings worldwide are available to purchase the debt. And fourth, our model has both traded and nontraded goods. This allows for a potentially important channel of policy transmission through changes in relative prices. ${ }^{4}$ 
In order to keep our model tractable, these advantages over the AK model are bought by making coarser assumptions along some other dimensions. We assume two-period lived agents, which leads to a time aggregation problem when attempting to match the model to the data. We also assume endowment economies, so that agents do not make adjustments on the labor-leisure margin and they do not accumulate capital.

The bottom line is that while our model is in the spirit of the $\mathrm{AK}$ model, it is intended to feature different channels of policy effects. Our model is for an open monetary economy, whereas the AK model is for a closed nonmonetary economy.

Not only is our model similar in spirit to that of $\mathrm{AK}$, but so is our approach to policy analysis. ${ }^{5}$ Like them, we determine policy effects by comparing simulations based on alternative policy assumptions. For this study we compare four simulations. The first simulation assumes that the monetary and budget policies of the late ' $70 \mathrm{~s}$ are maintained to generate a steady state. This simulation provides a baseline. The second simulation assumes a monetary policy shock that generates default on private debt, and it assumes no deposit insurance payments are made. ${ }^{6}$ By comparing the second simulation to the first, we can disentangle in the model how much of the deviation between the baseline and final outcome is due to the initial monetary policy shock which caused the default and how much is due to the deposit insurance financing policy. The third simulation alters the policy assumptions of the second by positing government deposit insurance payments which partially offset private defaults and which are funded by current taxation. By comparing the third simulation to the second, we can determine the extent to which deposit insurance payments balanced by current taxes can matter in our model. The fourth simulation replicates the third, except we assume that the deposit insurance payments are financed by a permanent roll-over of government bonds. By comparing the fourth simulation to the third, we can measure how important could be the choice of financing of deposit insurance payments. 
We report our simulations for a particular parameterized version of the model, but we conduct a sensitivity analysis to check its qualitative implications. The values of the parameters are chosen so that the model reasonably replicates certain features of the data from the 1980 s. Policy parameters are set based on their observed values. Unobservable parameters are set to provide both a reasonable steady state for the first simulation and an outcome for the fourth simulation-the simulation that assumes the policies actually followed-that reasonably matches the data. Thus, the empirically parameterized version of the model is essentially estimated based on one set of observations, and its estimates are very unreliable. Because of this, we conduct a sensitivity analysis by doing the same simulations for about 500 alternative sets of parameter values.

The simulations from the empirically parameterized version of the model suggest that the effects of deposit insurance financing could have been significant. They suggest that the decision to use debt financing rather than taxation raised the real interest rate by roughly 50 basis points. The sensitivity analysis suggests that whether or not the effects, in fact, have been significant, they likely worked qualitatively as the empirically parameterized version indicates.

\section{The Model}

We briefly describe the model in this section. A more complete discussion is in MillerTodd (1992).

\section{A. Structure}

In our model we consider two economies: the U.S. and the rest-of-world (ROW). Both have a private sector and a public sector. Both are populated by overlapping generations of agents who live two periods. At each integer date $t$ a new generation, generation $t$, appears. The members of generation $t$ are present at date $t$, when they are young, and at date $t+1$, when they are old. 
Each generation is made up of two types: service providers and farmers. Over time the number of each type of individual in each economy is constant, and individuals cannot switch types or economies. Without loss of generality, we set the number of each type in each generation equal to 1 .

The two types of individuals in each economy have identical preferences and differ only with respect to their endowments. The preferences are assumed to be represented by a discounted log-linear utility function, $U$, over service and food consumption in the two periods of an individual's life:

$$
\begin{aligned}
\mathrm{U}\left(\mathrm{c}_{\mathfrak{t}}\right) & \equiv \mathrm{U}\left(\mathrm{c}_{\mathrm{t}}^{\mathrm{S}}(\mathrm{t}), \mathrm{c}_{\mathrm{t}}^{\mathrm{F}}(\mathrm{t}), \mathrm{c}_{\mathrm{t}}^{\mathrm{S}}(\mathrm{t}+1), \mathrm{c}_{\mathrm{t}}^{\mathrm{P}}(\mathrm{t}+1)\right) \\
& =\theta \log \mathrm{c}_{\mathrm{t}}^{\mathrm{S}}(\mathrm{t})+(1-\theta) \log \mathrm{c}_{\mathrm{t}}^{\mathrm{P}}(\mathrm{t})+\delta\left[\theta \log \mathrm{c}_{\mathrm{t}}^{\mathrm{S}}(\mathrm{t}+1)+(1-\theta) \log \mathrm{c}_{\mathrm{t}}^{\mathrm{F}}(\mathrm{t}+1)\right],
\end{aligned}
$$

where

$\mathrm{S}$ is services, and $\mathrm{F}$ is food,

$\theta$ is a parameter reflecting relative preferences for services versus food,

$\delta$ is a parameter reflecting the rate of time preference,

a subscript $t$ refers to a member of generation $t$, and

an integer in parentheses is a date.

The endowments of the two types of individuals differ with respect to both the type of goods and the pattern of goods over time. The endowment of a generation $t$ service provider $\mathrm{w}_{\mathrm{t}: \mathrm{S}}$ is assumed to be:

$$
w_{t: S} \equiv\left[w_{t: S}^{S}(t), w_{t: S}^{P}(t), w_{t: S}^{S}(t+1), w_{t: S}^{p}(t+1)\right]=\left[w_{t}^{s}(t), 0,0,0\right],
$$

where

$$
w_{t}^{s}(t)>0 .
$$


Thus, service providers are endowed with all of their country's services in their first period of life and with nothing else. The endowment of a generation $t$ farmer, $w_{t: F}$, is assumed to be:

$$
w_{t: F} \equiv\left[w_{t: F}^{s}(t), w_{t: P}^{P}(t), w_{t: P}^{s}(t+1), w_{t: P}^{P}(t+1)\right]=\left[0, w_{t}^{P}(t), 0, w_{t}^{P}(t+1)\right],
$$

where

$$
w_{t}^{\mathrm{P}}(t+1)>w_{t}^{\mathrm{P}}(t) \geq 0 .
$$

Farmers are endowed with some positive amount of food in their second period of life and with a lesser amount, perhaps zero, in the first period.

The preferences and the endowments are taken to be the same in both economies, but the policy parameters, and hence, prices and allocations can differ between the two. To distinguish the economies, we use a superscript asterisk on foreign variables or functions. For example, foreign preferences are represented by $U\left(c_{t}^{*}\right)$.

The pattern of endowments is intended to proxy for production, which is not included in our model. We think of service providers as supplying labor-intensive goods with a relatively short production lag. Hence, their endowment is concentrated in the first period of life. We think of farmers as supplying a capital-intensive good subject to a relatively long production lag that requires high initial investment. Hence, their endowment is concentrated in the second period of life. There is no storage. Because of the different endowment patterns, in equilibrium service providers lend and farmers borrow. We assume all private debt is in the form of one-period discount bonds, $\mathrm{B}^{\mathrm{P}}$. We take these to be nominal (nonindexed) bonds denominated in the currency of the economy where the issuer resides.

Farmers are distinguished by two characteristics in our model. One is that they are borrowers. A second is that only their good is world traded. While services and food can be purchased and sold within an economy, only food can be traded between economies. 
In addition to a private sector, both economies have a public sector. The public sector has a fiscal authority that consumes some amounts of its economy's service and food and levies lumpsum real taxes, quoted in food units, on service providers and farmers. We assume that its total consumption always matches or exceeds its total lump-sum tax revenue. (This permanent deficit assumption implies that, in steady states, inflation must be positive to generate the seignorage needed to finance government deficits.) An economy's budget policy is defined by the fiscal authority's real consumption of services and food, $\mathrm{g}^{\mathrm{S}} \geq 0$ and $\mathrm{g}^{\mathrm{F}} \geq 0$, respectively; by its lump-sum taxes on service providers and farmers $\tau_{\mathrm{S}}$ and $\tau_{\mathrm{P}}$, respectively; and by its issue of one-period discount bonds, $\mathrm{B}^{\mathrm{G}}$, to finance the deficit. ${ }^{7}$

Each public sector also has a monetary authority that engages in open-market operations and imposes a reserve requirement. Open-market operations are conducted by exchanging fiat money for government bonds, and the reserve requirement is specified by a fraction of nominal savings which must be held in the form of money. An economy's monetary policy is defined by the ratio of government bonds to money, $\beta$, and by the reserve requirement, $\lambda$. Government bonds are traded in a world capital market, but in equilibrium an economy's money is held only by domestic lenders to satisfy reserve requirements.

\section{B. Market Equilibrium}

A market equilibrium is defined as an allocation of goods and sequences of prices such that at each date the allocation solves individual optimization problems given the prices, the quantities and prices are consistent with the two governments' budget constraints, and markets clear. There are six markets in the model: two world markets in food and bonds, and four domestic markets in economy-specific services and money. By Walras's Law we eliminate separate consideration of the world bond market. In the remaining markets five price sequences are determined: the world real 
interest rate $(\rho)$, the relative price of services to food in each economy ( $Q$ and $\left.Q^{*}\right)$, and the rate of change of food prices in each economy $\left(\pi^{\mathrm{F}}\right.$ and $\left.\pi^{\mathrm{F}}\right)$. All other prices and quantities can be determined using these five price sequences.

We next describe individual optimization problems, government budget constraints, and market clearing conditions. We conclude this subsection with a description of an equilibrium.

\section{Individual Optimization Problems}

We describe the optimization problems of the old at date 1 (generation 0 ) and of the young at all dates (generation $t>0$ ). We only consider the home economy, since the individuals solve parallel problems in the foreign economy. Individuals take prices as given and have perfect foresight with respect to prices in their second period of life.

The old at $\mathrm{t}=1$ maximize:

$$
\theta \log \mathrm{c}_{0}^{\mathrm{S}}(1)+(1-\theta) \log \mathrm{c}_{0}^{\mathrm{F}}(1)
$$

subject to

$$
Q(1) c_{0}^{S}(1)+c_{0}^{F}(1)=A_{0}
$$

where

$$
A_{0} \equiv\left\{\begin{array}{cl}
\frac{H(0)+B^{G}(0)}{p^{F}(1)}+\frac{B^{P}(0)}{p^{F}(1)}-\tau_{s}(1: \text { old }) & \text { for service providers } \\
w_{0}^{F}-\frac{B^{P}(0)}{p^{F}(1)}-\tau_{F}(1: \text { old }) & \text { for farmers }
\end{array}\right.
$$

and where $\mathrm{Q}(1) \equiv\left[\mathrm{p}^{\mathrm{S}}(1) / \mathrm{p}^{\mathrm{P}}(1)\right]$ is the relative price of services to food at date 1 . The real wealth of old service providers consists of the outside debt (money and bonds) of their government and the private debt of their economy's farmers-both deflated by the level of food prices-less the lump-sum 
tax. The real wealth of old farmers consists of their food endowment less the real value of the debt they have outstanding less the lump-sum tax. Note that for both types of old agents at $t=1$, the real value of $A_{0}$ depends on $p^{\mathrm{F}}(1)$, an endogenous variable subject to the effects of policy changes in period 1.

The optimization problem generates the usual Cobb-Douglas utility demand functions:

$$
\hat{\mathrm{c}}_{0}^{\mathrm{S}}(1)=\theta \mathrm{A}_{0} / \mathrm{Q}(1)
$$

and

$$
\hat{c}_{0}^{\mathrm{F}}(1)=(1-\theta) \mathrm{A}_{0}
$$

where $A_{0}$ takes on the values specified above for old service providers and farmers, respectively. Agents born at dates $t \geqq 1$ maximize

$$
\theta \log c_{t}^{\mathrm{S}}(\mathrm{t})+(1-\theta) \log \mathrm{c}_{\mathrm{t}}^{\mathrm{P}}(\mathrm{t})+\delta\left[\theta \log \mathrm{c}_{\mathrm{t}}^{\mathrm{S}}(\mathrm{t}+1)+(1-\theta) \log \mathrm{c}_{\mathrm{t}}^{\mathrm{F}}(\mathrm{t}+1)\right]
$$

subject to

$$
\mathrm{W}(\mathrm{t})=\mathrm{Q}(\mathrm{t}) \mathrm{c}_{\mathrm{t}}^{\mathrm{S}}(\mathrm{t})+\mathrm{c}_{\mathrm{t}}^{\mathrm{P}}(\mathrm{t})+\left[\mathrm{Q}(\mathrm{t}+1) \mathrm{c}_{\mathrm{t}}^{\mathrm{S}}(\mathrm{t}+1)+\mathrm{c}_{\mathrm{t}}^{\mathrm{P}}(\mathrm{t}+1)\right] /(1+\mathrm{i}(\mathrm{t})),
$$

where

$$
\begin{aligned}
& \mathrm{W}(\mathrm{t}) \equiv \begin{cases}\mathrm{Q}(\mathrm{t}) \mathrm{w}_{\mathrm{t}}^{\mathrm{S}}(\mathrm{t})-\tau_{\mathrm{s}}(\mathrm{t}), & \text { for service providers } \\
\mathrm{w}_{\mathrm{t}}^{\mathrm{P}}(\mathrm{t})+\frac{\mathrm{w}_{\mathrm{t}}^{\mathrm{P}}(\mathrm{t}+1)}{1+\rho(\mathrm{t})}-\tau_{\mathrm{F}}(\mathrm{t}), & \text { for farmers }\end{cases} \\
& 1+\mathrm{i}(\mathrm{t}) \equiv \begin{cases}1+\rho_{\mathrm{s}}(\mathrm{t}) & \text { for service providers } \\
1+\rho(\mathrm{t}) & \text { for farmers }\end{cases}
\end{aligned}
$$


$r(t) \equiv$ the nominal interest rate on one-period bonds issued at $t$;

$\pi^{F}(t) \equiv p^{F}(t+1) / p^{F}(t)-1$, the rate of food price inflation from $t$ to $t+1$

$\rho(t) \equiv[1+\mathrm{r}(\mathrm{t})] /\left[1+\pi^{\mathrm{P}}(\mathrm{t})\right]-1$, the real rate of return on one-period bonds issued at $t$; and

$\rho_{\mathrm{S}}(\mathrm{t}) \equiv[1+(1-\lambda(\mathrm{t})) \mathrm{r}(\mathrm{t})] /\left[1+\pi^{\mathrm{F}}(\mathrm{t})\right]-1$, the real rate of return on savings at $\mathrm{t}$.

Note that after the first period, taxes are levied only on the young in a generation. Also note that the wealth of lenders (service providers) doesn't depend just on the real rate of return on bonds. Because lenders are legally required to hold a fraction of their assets as domestic currency, their net nominal rate of return is not $r$, the net nominal rate on bonds, but rather $(1-\lambda) r$, where $\lambda$ is the fraction of their assets that savers must hold in the form of money (dependence on $t$ is being suppressed). It follows that the real rates earned by savers and paid by borrowers are related by $1+\rho_{\mathrm{S}}=\lambda /(1+\pi)+(1-\lambda)(1+\rho)$. Only when $\lambda=0$, are the two rates the same.

The optimization problem again generates typical Cobb-Douglas utility demand functions:

$$
\begin{aligned}
& \hat{c}_{\mathfrak{t}}^{\mathrm{S}}(\mathrm{t})=\left(\frac{\theta}{1+\delta}\right) \mathrm{W}(\mathrm{t}) / \mathrm{Q}(\mathrm{t}), \\
& \hat{\mathrm{c}}_{\mathrm{t}}^{\mathrm{T}}(\mathrm{t})=\left[\frac{1-\theta}{1+\delta}\right] \mathrm{W}(\mathrm{t}), \\
& \hat{\mathrm{c}}_{\mathrm{t}}^{\mathrm{s}}(\mathrm{t}+1)=\left(\frac{\theta \delta}{1+\delta}\right)\left(\frac{\mathrm{W}(\mathrm{t})}{\mathrm{Q}(\mathrm{t}+1)}\right)
\end{aligned}
$$

and

$$
\mathcal{c}_{\mathrm{l}}^{\mathrm{P}}(\mathrm{t}+1)=\left[\frac{(1-\theta) \delta}{1+\delta}\right][\mathrm{W}(\mathrm{t})(1+\mathrm{i}(\mathrm{t}))]
$$

\section{Government Budget Constraint}

The government at date $t$ pays for current expenditures and the retirement of last period's bonds and money by issuing new bonds and money and by levying lump-sum taxes: 


$$
\mathrm{p}^{\mathrm{S}}(\mathrm{t}) \mathrm{g}^{\mathrm{S}}(\mathrm{t})+\mathrm{p}^{\mathrm{F}}(\mathrm{t}) \mathrm{g}^{\mathrm{F}}(\mathrm{t})+\mathrm{B}^{\mathrm{G}}(\mathrm{t}-1)+\mathrm{H}(\mathrm{t}-1)=\mathrm{P}^{\mathrm{B}}(\mathrm{t}) \mathrm{B}^{\mathrm{G}}(\mathrm{t})+\mathrm{H}(\mathrm{t})+\mathrm{p}^{\mathrm{P}}(\mathrm{t}) \tau(\mathrm{t}),
$$

where

$P^{B}(t)$ is the nominal price of government bonds at date $t$,

$p^{B}(t)=1 /(1+r(t))$

$\mathrm{B}^{\mathrm{G}}(\cdot)$ is the total nominal face value of government bonds,

$\mathrm{H}(\cdot)$ is the total quantity of money, and

$\tau(t)$ is the sum of taxes net of transfers in food units at date $t$.

Let the real value of bonds and money in terms of food at date $t$ be defined respectively by:

$$
b^{G}(t) \equiv \frac{P^{B}(t) B^{G}(t)}{p^{F}(t)}
$$

and

$$
h(t) \equiv \frac{H(t)}{p^{P}(t)}
$$

In addition, let $\beta(t) \equiv \mathrm{B}^{\mathrm{G}}(\mathrm{t}) / \mathrm{H}(\mathrm{t})$.

Then the government budget constraint can be written

$$
\mathrm{Q}(\mathrm{t}) \mathrm{g}^{\mathrm{s}}(\mathrm{t})+\mathrm{g}^{\mathrm{F}}(\mathrm{t})-\tau(\mathrm{t})=\left[\frac{1+\mathrm{r}(\mathrm{t})+\beta(\mathrm{t})}{1+\mathrm{r}(\mathrm{t})}\right] \mathrm{h}(\mathrm{t})-\frac{[1+\beta(\mathrm{t}-1)]}{\left[1+\pi^{\mathrm{F}}(\mathrm{t}-1)\right]} \mathrm{h}(\mathrm{t}-1)
$$

\section{Market Clearing Conditions}

We first define selected price variables and then express relationships among them which must hold in equilibrium. The aggregate price level in a particular economy is defined as:

$$
\mathrm{P}(\mathrm{t}) \equiv \mathrm{p}^{\mathrm{s}}(\mathrm{t})^{\theta} \mathrm{p}^{\mathrm{F}(\mathrm{t})^{(1-\theta)}}
$$

a measure of the minimal cost of one unit of utility.

The nominal exchange rate e defines how many units of the foreign economy's currency are exchanged for one unit of the home economy's currency. By the Law of One Price applied to the 
traded good, we get that $e(t) p^{F}(t)=p^{F^{*}}(t)$, or $e(t)=p^{F^{*}}(t) / p^{F}(t)$. The real exchange rate then is defined as the nominal exchange rate divided by the ratio of the price levels, or:

$$
\overline{\mathrm{e}}(\mathrm{t}) \equiv \mathrm{e}(\mathrm{t}) /\left[\mathrm{P}^{*}(\mathrm{t}) / \mathrm{P}(\mathrm{t})\right]=\left[\mathrm{Q}(\mathrm{t}) / \mathrm{Q}^{*}(\mathrm{t})\right]^{\theta}
$$

Since private and government bonds within an economy are perfect substitutes, their nominal (as well as real) rates of return must be the same in equilibrium-a fact we already used in stating the optimization problems. Moreover, because domestic and foreign bonds are perfect substitutes, it follows that the real interest rates in equilibrium must be the same in each economy:

$$
\frac{1+r(t)}{1+\pi^{F}(t)} \equiv 1+\rho(t)=1+\rho^{*}(t) \equiv \frac{1+r^{*}(t)}{1+\pi^{F^{*}}(t)}
$$

We'll refer to this single real rate as $\rho(t)$.

\section{Equilibrium}

All equilibrium quantities and prices can be derived from the equilibrium values of the five sequences $\rho, Q, Q^{*}, \pi^{\mathrm{F}}$, and $\pi^{\mathrm{F}^{*}}$. These sequences can be derived by equating demand and supply in the goods and money markets. Market demands and supplies are found by adding up the individual demands and supplies of the agents and governments that participate in the markets.

We are able to specify a set of parameter vectors such that for each vector in the set we can guarantee that there exists a unique equilibrium in which all real quantities are unchanging over time. This set does not include all the parameter vectors for which such an equilibrium exists, however. In fact, the parameter vector that yields the baseline equilibrium for our experiments lies outside this set. We have checked numerically for evidence of multiple equilibria associated with this vector and have found none. 


\section{Policy Experiments}

\section{The Nature of the Experiments}

Our policy experiments are conducted by comparing outcomes under different sets of assumptions. For given parameter values we compute equilibrium paths for four sets of assumptions. The first set is used to generate baseline values. We assume patterns of endowments and policy parameters such that the economy is in a steady-state equilibrium; that is, relative prices, rates of return, and real quantities are unchanging over time. We associate this equilibrium with the position of the economy prior to $1979-80$.

Our second set of assumptions is used to generate default on private debt. This set differs from the first set in two ways. One is that we assume an unforeseen once-and-for-all tightening of monetary policy in period 1 ; that is $\beta(\mathrm{t})^{\prime}>\beta(\mathrm{t})$ for $\mathrm{t} \geqq 1 .^{8}$ This generates a lower price $\mathrm{p}^{\mathrm{F}}(1)^{\prime}$ than in the baseline $\mathrm{p}^{\mathrm{P}}(1)$. We interpret this as a deflationary surprise to the old agents in period 1 who had borrowed and lent expecting a continuation of baseline policies. The other way our second set of assumptions differs from the first is that we assume the old borrowers default on part of their debt. Instead of paying back $\mathrm{B}^{\mathrm{P}}(0)$, they pay back only $\mathrm{B}^{\mathrm{P}}(0)^{\prime}$ so that their real debt payments are left unchanged; that is, $\mathrm{B}^{\mathrm{P}}(0)^{\prime} / \mathrm{p}^{\mathrm{F}}(1)^{\prime}=\mathrm{B}^{\mathrm{P}}(0) / \mathrm{p}^{\mathrm{F}}(1)$ with $\mathrm{p}^{\mathrm{F}}(1)^{\prime}<\mathrm{p}^{\mathrm{F}}(1)$ and $\mathrm{B}^{\mathrm{P}}(0)^{\prime}<\mathrm{B}^{\mathrm{P}}(0)$.

Our third set of assumptions is used to determine the effects of deposit insurance payments which are financed by taxation. We alter the second set of assumptions by having the government transfer to the old lenders a fraction $\mathrm{k}$ of the amount defaulted on the debt:

$$
-\tau_{\mathrm{S}}(1: \text { old })=\mathrm{k} \cdot\left(\mathrm{B}^{\mathrm{P}}(0)-\mathrm{B}^{\mathrm{P}}(0)^{\prime}\right) / \mathrm{p}^{\mathrm{P}}(1)^{\prime} .
$$

We take $\mathrm{k}<1$, since in the U.S. not all defaulted debt was insured. For this set of assumptions we have the government raise taxes on young savers and borrowers to pay for the transfers: 


$$
\tau_{\mathrm{F}}(1, \text { young })+\tau_{\mathrm{S}}(1, \text { young })=-\tau_{\mathrm{S}}(1, \text { old })
$$

Our fourth set of assumptions is used to determine the effects of deposit insurance payments which are financed by debt issue. The payouts are made as in the previous set of assumptions, but now we assume the government does not raise taxes. Instead, it increases its borrowing:

$$
\Delta\left(\mathrm{P}^{\mathrm{B}}(1) \mathrm{B}^{\mathrm{G}}(1)\right)=\mathrm{k} \cdot\left(\mathrm{B}^{\mathrm{P}}(0)-\mathrm{B}^{\mathrm{P}}(0)^{\prime}\right)=-\tau^{\mathrm{S}}(1: \text { old }) \mathrm{p}^{\mathrm{P}}(1)^{\prime} .
$$

We assume that the monetary authority does not accommodate the increase in government borrowing, so that

$$
\mathrm{H}(1)^{\prime \prime}=\mathrm{H}(1)^{\prime} \text { and } \frac{\mathrm{B}^{\mathrm{G}}(1)^{\prime \prime}}{\mathrm{H}(1)^{\prime}}=\beta(1)^{\prime \prime}>\beta(1)^{\prime}=\frac{\mathrm{B}^{\mathrm{G}}(1)^{\prime}}{\mathrm{H}(1)^{\prime}} \text {, }
$$

where the initial paths are as in assumption set 2 .

In all future periods monetary policy is constant; that is, $\beta(t)^{n}=\beta(1)^{\prime \prime}$ for $t \geqq 2$.

Our policy experiments consist of comparing outcomes under different sets of assumptions. They are intended to assess the impacts of different aspects of the deposit insurance payout program. We conduct 3 experiments (see Table 1).

\section{Measurement of Effects}

We conduct our policy experiments when the parameters of the model are given numerical values. We focus on the outcomes for an empirically-based set of values, but we also do a sensitivity analysis in which we conduct the same experiments for a fairly large sample of sets of parameter values. The sensitivity analysis confirms that the directions of effects from the empirical data set are the predominant ones. Ideally, the qualitative results would have been derived analytically. However, our model is too complicated to permit an analytical approach. 
The parameter sets we consider differ with respect to values representing endowments, preferences, and policies initially in place. For the sensitivity analysis 500 sets of parameter values are chosen randomly from a space where each set implies a unique steady state. We restrict our parameter sets to ones for which the endowment patterns are the same in the U.S. and ROW and the initial old in each country hold no foreign debt.

For the sensitivity analysis, we generate four outcomes for comparison and note for each comparison the percentage of times variables of interest either rise or fall. Since short-run effects can be in the opposite direction of long-run effects, we do the comparisons for each of the first three periods and steady-state. The first outcome is the equilibrium associated with an initial, randomly selected parameter set. The second outcome is generated by permanently increasing $\beta$ by 1 percent starting in the first period and having borrowers who are old in the first period default an amount on their debt that leaves their real debt payments the same as they were in the first outcome. The third outcome is generated by having transfer payments to old savers in the first period cover onefourth of the default on their private debt holdings and taxing first-period young savers and borrowers by equal amounts in order to finance the transfers. ${ }^{9}$ The fourth outcome is generated the same as the third except the transfers are financed by debt issue.

For the empirically-based parameter set, the home and foreign economies are assumed to be identical initially. Policy parameters then are chosen to roughly characterize the policies in place in the late 1970's. Lump-sum taxes $\tau$ are initially set at zero, and $\mathbf{g}^{\mathrm{F}}$ and $\mathrm{g}^{\mathrm{S}}$ are chosen so that the net-of-interest deficit $\mathrm{p}^{\mathrm{F}}(1) \mathrm{g}^{\mathrm{F}}+\mathrm{p}^{\mathrm{S}}(1) \mathrm{g}^{\mathrm{S}}$ is equal to 0.75 percent of GNP-roughly matching the U.S. average for that period. The reserve requirement $\lambda$ is set at 0.10 percent to imply an initial ratio of base money to GNP of 6.0 percent-again about matching the U.S. average for that period. Similarly, the ratio of government bonds to money $\beta$ is set at 3.0 (see Miller-Roberds 1991). We chose the time 0 money stocks to imply initial price levels equal to 1 . 
Initial values of endowment and taste parameters are chosen partly to generate reasonable initial values for the annualized rates of real interest and inflation -0.8 percent and 8.9 percent, respectively. They also are chosen to generate reasonable quantitative estimates of the changes in the real interest rate, real exchange rate, inflation rates, and current account balances coming from an increase in $\beta$ from 3.0 to $4.0 .^{10}$ We take the total endowments of food and services to be the same in each country, which implies the sizes of the tradeable and nontradeable goods sectors are the same. ${ }^{11}$ ("Tradeable" means goods that can be traded, e.g., autos, and not goods actually traded e.g., auto exports.) We arbitrarily assume preferences weight traded and nontraded goods the same, so that initial relative prices and the real exchange rate are equal to 1.0 .

In order to generate outcomes $2-4$ we adjust some policy parameters for the U.S., keeping all other parameters for the U.S. and ROW unchanged. We chose the initial monetary policy change in $\beta$ so that that change, coupled with the further rise in $\beta$ caused by debt financing of deposit insurance payments, move $\beta$ up from 3 to 4 . For the payments we assume that the government makes up one-fourth of the defaults, which together with our other assumptions implies total deposit insurance payments of roughly $\$ 16$ billion. This annual cost is consistent with one year of actual transfer payments associated with the deposit insurance program, assuming the actual total payment is spread over 10 years. (For our empirically-based parameter assumptions, see Table 2.)

\section{Discussion of Results}

We report the results of our simulations based on the empirically-based parameter set. Our sensitivity analysis suggests the direction (but not the size) of effects is typical. So even if our numerical estimates are discounted, the analysis still could be useful in providing insights about how prices and aggregate quantities are affected by the deposit insurance payout program and about who gains and who loses. ${ }^{12}$ 
Experiment 1. Default with no deposit insurance payments (Outcome 2 vs. Outcome 1). This experiment assumes that changes in the level of payments do not alter the deposit insurance system or the effects of that system on behavior towards risk. The assumption is made for hypothetical reasons to allow us to focus on the transfer and financing aspect of deposit insurance. The key change in experiment 1 is that the monetary authority unexpectedly tightens. In particular, it conducts open-market sales to raise the value of the bond-money ratio from its steady state value of 3 to a new value of 3.6 at time 1 and thereafter. No other policies change. ${ }^{13}$ Under these circumstances, the shift toward bond financing of the U.S. government's debt raises the worldwide real interest rate in time 1 and beyond by about 170 basis points. (See Table 3.)

The effects of the tightening on many other variables differ between period 1 and the later periods, so we will begin by examining period 1. The open market sale reduces the stock of U.S. money and thereby pushes the time 1 price level in the U.S. below its time 1 level in the baseline, as inflation falls from 8.8 in the steady state to 0.8 percent between times 0 and 1 . This enhances the apparent real value of outstanding nominal private and public bonds in the U.S., which are held by the initial old savers in the U.S. They receive part of this windfall; the U.S. government pays off its nominal bonds in full. Private debtors balk, however. They force a renegotiation under which they pay only the amount of food they would have owed if prices had stayed on the baseline path. This default amounts to about 1.3 percent of aggregate U.S. endowment. In the true U.S. economy, this would amount to about $\$ 65$ billion dollars. Considering that in the U.S. banks alone were allocating over $\$ 30$ billion a year in the late 1980 s to cover loan losses, the size of this default does not seem excessive.

Default by private debtors has no effect on aggregate variables in our model. Initial old debtors and creditors have identical preferences in our model. Therefore, a transfer of wealth from one of these two groups to the other doesn't affect their aggregate consumption, only how that 
consumption is split between them. It is then obvious that the default makes initial lenders worse off than if the monetary tightening had occurred and borrowers had paid off in full.

With a little reflection, however, it is fairly obvious that even this partial default does not make the initial lenders worse off than if the monetary authority had not tightened in the first place. From the initial borrowers, the initial old receive in real terms exactly what they would have received in the baseline. From the government, however, they receive more, due to the unanticipated appreciation of their safe government bonds. This result could obviously be overturned if the private default were larger, but it illustrates an interesting possibility: defaults notwithstanding, U.S. savers as a group (ignoring the distribution of defaults among them) may have been "wealthier" even before deposit insurance payments, if the alternative was a policy with no monetary tightening.

The increase in wealth that the initial old collectively receive from the appreciation of the initial stock of U.S. bonds does have aggregate effects, regardless of how that increase is split between them by a possible default. These effects stem solely from the monetary tightening, and outcome 2 thus also stands as an alternative baseline for experiments 2 and 3 . It allows us to separate the effects of deposit insurance payments and their financing from the effects of monetary tightening in those experiments, where both effects are present.

Because the initial U.S. old are collectively enriched by a monetary tightening, their consumption will rise. The higher real interest rate produced by the tightening also boosts the wealth and consumption of young U.S. lenders at time 1. In the U.S. at time 1, only young borrowers are hurt by the tightening. It turns out that the net effect is an increase in U.S. aggregate consumption at time 1. Since the U.S. supply of nontraded goods is fixed, the entire increase in consumption consists of an increase in food imports. Under the baseline, U.S. food consumption equaled the U.S. food endowment. As a result of the monetary tightening, at time 1 the U.S. increases its trade deficit from zero to about 0.3 percent of GNP (equivalent to toughly 13 billion dollars in today's 
U.S. economy), the price of food relative to services in the U.S. falls about 0.5 percent, and the real exchange value of the dollar strengthens by 0.5 percent. ${ }^{14}$

Many of the time 1 effects are reversed in later periods. The driving force is a switch in relative inflation rates. Measuring from time 0 to time 1 , the tightening caused disinflation in the U.S. and higher inflation in the ROW, relative to the baseline. From time 1 forward, however, the monetary tightening causes U.S. inflation to outstrip inflation in the ROW. In fact, U.S. inflation runs at 15.6 to 17.8 percent from time 1 forward, while ROW inflation runs at only 12.8 to 14.7 percent.

The budgetary implications of monetary tightening are what boost future U.S. inflation rates above those of the ROW. With its open market sale, the monetary authority has both increased the time 1 stock of bonds and raised the real interest rate. We are assuming in experiment 1 that fiscal policy is unchanged, so taxes will not be raised in time 1 or later to pay either the principal or the interest on the enlarged and more expensive stock of government debt. Instead, when the higher interest payments on its enlarged debt start coming due in time 2 and later, the government will meet them partly by money and partly by bonds, so that it will print more money than in the baseline. The rate of inflation from time 1 to time 2 , from time 2 to time 3 , and so on, will thus be higher in the U.S. than in the baseline. Because the ROW government also now pays higher interest on its debt, ROW inflation from time 1 forward also rises. The effect is smaller, however, because the ROW government did not use open market sales to increase its stock of bonds at time 1 .

We have seen how relative disinflation at time 1 increased the wealth of the U.S. old and stimulated imports, a relative decline in U.S. food prices, and an appreciation of the dollar. The same effects operate in reverse in later periods, when the inflation rate is higher in the U.S. than in the ROW. 
Inflation differentials have no direct effect on borrowers in either country, so the effects of differing inflation rates stem from the impact of inflation on the wealth of savers. Because of reserve requirements that force savers to hold 10 percent of their savings in the form of zero-interest currency, the overall real rate of return on savings is determined 90 percent by the worldwide real interest rate and 10 percent by the real rate of return on currency. The former is common to U.S. and ROW savers, but the latter is the reciprocal of each country's inflation rate. Higher inflation in the U.S. from time 1 forward thus pushes the return on savings in the U.S. below the return on savings in the ROW, and this gives ROW savers greater wealth than U.S. savers in the second period of life.

For U.S. savers born at time 1 , this effect is offset by the fact that U.S. relative prices have moved in favor of services, the good we have assumed savers are endowed with. Hence at time 2 the old savers in the U.S. are still a bit wealthier than the ROW old savers, the U.S. still imports food and runs a trade deficit, and the relative price of services is still higher in the U.S. than in the ROW. In fact, U.S. services prices are still relatively high enough to tilt relative wealth and food imports towards the U.S. for one more period.

For U.S. savers born at time 3 or later, however, the negative effects of higher U.S. inflation dominate, leaving them poorer than their ROW counterparts. By time 4, then, the U.S. is on its way to a new steady state in which it exports food, runs a trade surplus of about $\$ 0.4$ billion $(0.01$ percent of GNP), and has a 0.02 percent rise in the relative price of food and a 0.02 percent cut in the real value of the dollar, relative to the baseline.

These aggregate and price impacts naturally affect individuals' utilities. (See column 1 of Table 4.) As explained above, the monetary tightening leaves initial old savers in the U.S. better off despite the partial default of their private creditors. The magnitude of the improvement can be thought of as about 2.6 percent, in the sense that they could give up about 2.6 percent of their 
outcome 2 consumption and still be better off than under the baseline. By the same standard, which we will use repeatedly when comparing levels of well-being, the initial old borrowers in the U.S. are about 0.3 percent worse off than in the baseline. This is because although default freezes their real debt burden at its baseline level, the monetary tightening lowers the relative price of food, which is their endowment good. In the ROW, the position of the initial old is the reverse: initial old savers are about 0.3 percent worse off because of a slight increase in the time 1 ROW price level, while initial old borrowers are about 0.6 percent better off because of the higher price level and the increase in the relative price of food in the ROW.

The young born in period 1 experience a mixture of effects unique to time 1 and effects that will prevail in period 2 and all subsequent periods. In the U.S., higher interest rates and the high relative price of nontraded goods helps young savers, while higher inflation hurts them. The net effect is to make them about 1.5 percent better off than in the baseline. Young borrowers, however, suffer both higher interest rates and a decline in the relative value of food, their endowment good. They are 1.4 percent worse off than in the baseline. Interest rate effects dominate in the ROW. Despite a low relative price on nontraded goods, ROW savers are 0.5 percent better off and ROW borrowers are 0.7 percent worse off than in the baseline.

For the young born at later dates, the direction of the effects are the same as for the young born at time 1 , mainly because at all dates interest rate effects dominate the welfare of the young. The magnitudes change somewhat (see Table 3), mainly because relative prices gradually shift, with traded goods becoming expensive relative to nontraded goods in the U.S. and relatively cheap in the ROW. Note that the fact that U.S. savers are always better off in outcome 2 than in the baseline does not contradict the claim above that from period 3 on newly born savers in the ROW are wealthier than those in the U.S. 
Experiment 2. Deposit insurance payments financed by taxation (Outcome 3 vs. Outcome 2). Experiment 1 gives a hypothetical account of what would have happened if no deposit insurance payments were made in the U.S. In Experiment 2, U.S. monetary authorities tighten and initial private borrowers in the U.S. default, as before. Now, however, the U.S. government reimburses its initial old savers for 25 percent of the amount of the default. This amounts to about 0.32 percent of U.S. aggregate endowment, or the equivalent in the actual U.S. economy of about $\$ 16$ billion. To cover this expense, the government increases the lump-sum tax on each young saver and borrower at time 1 by a fixed amount.

If we focus on prices and quantities, the effects of paying deposit insurance and financing it with taxes seem modest except at time 1. Comparing columns 3 and 2 of Table 2 shows that, in time 1, tax-financed deposit insurance in the U.S. boosts worldwide real interest rates by 31 basis points and boosts U.S. inflation from time 1 to time 2 by 0.26 percentage points. It also increases both the relative U.S. price of nontraded goods and the real appreciation of the dollar from 0.52 to 0.61 percent, and it changes the trade deficit from 0.26 percent of GNP (equivalent to about $\$ 13$ billion) to 0.31 percent of GNP (equivalent to over $\$ 15$ billion).

All of these effects stem from the fact that deposit insurance payments financed by taxes transfers resources from the young to the old in the U.S. Since the old have no incentive to save, they spend all of this transfer. The young, by contrast, do not reduce their consumption by the full amount of taxes they pay to finance the transfer. Instead, to avoid a sharp difference in their time 1 and time 2 consumption levels as a result of having some of their wealth taxed away at time 1 , young savers cut back on their saving and young borrowers increase their borrowing, relative to the levels of outcome 2. The net effect is a further increase in aggregate U.S. demand for both goods and credit at time 1 , beyond the levels produced in outcome 2 by monetary tightening alone. To pay 
the higher interest rate on time 1 government debt, more money will have to be issued in time 2 , which explains the higher forward looking inflation rate.

The U.S. rate of inflation from time 0 to time 1 is also 0.3 percentage points higher in outcome 3 than in outcome 2 , although it remains almost 8 percentage points below the rate in the baseline. The small difference between outcomes 2 and 3 stems from the tax on young savers. The tax lowers their wealth and thus their savings, and this in turn lowers their demand for money to hold as reserves. This means that, in our model, financing deposit insurance by taxes on the current young actually reduces the total insurance payout by lessening the disinflation between periods 0 and 1. The effect is small, however, cutting the total default from 1.3 percent of aggregate supply in outcome 2 to 1.2 percent in outcome 3 .

After time 1, the aggregate effects of experiments 1 and 2 look very similar, and in the long run they are virtually identical. This is because deposit insurance in experiment 2 mainly involves transfers of wealth among those alive at time 1 . One legacy for future generations in both countries is a somewhat enlarged government debt burden attributable to the higher real interest rates of period 1. Another legacy is a the debt that private U.S. borrowers owe the ROW savers who financed them in period 1. These account for most of the small differences between outcomes 2 and 3 at time 2. As these two legacies gradually disappear over ensuing generations, the differences between the two experiments vanish.

Columns 1 and 2 of Table 4 show that the welfare effects of making tax financed deposit insurance payments are also concentrated in period 1. The initial old savers in the U.S. are naturally the big winners. Monetary tightening, default, and partial deposit insurance make them 1.1 percent better off than monetary tightening and default alone, and they are 3.7 percent better off than with no monetary tightening (and hence no default or insurance). The big losers are the U.S. young at time 1, especially young borrowers. Young borrowers face increased taxes and higher interest rates 
that leave them about 0.8 percent worse off than in experiment 2 . Higher interest rates partly offset the increased tax burden for young U.S. savers, so that outcome 3 makes them only about 0.2 percent worse off than they are in outcome 2 . Furthermore, they remain 1.4 percent better off than under the baseline. Clearly these conclusions about the relative positions of young U.S. savers and borrowers at time 1 could easily be changed, with little effect on economic aggregates or other agents, by changing the distribution of the tax increases to favor the one group or the other.

The change from experiment 1 to experiment 2 has only minor impacts on the welfare of agents other than those discussed above. Most of the small effects are easily explained either by lingering temporary interest rate differences or by the temporary relative and nominal price effects discussed above.

Experiment 2 shows that deposit insurance payments financed by contemporaneous tax hikes could have some nontrivial effects. Most clearly, the payments benefit those who receive them and hurt those who are taxed to provide them. They also contribute to modest bulges in real interest rates and the U.S. trade deficit. Their effects on prices and aggregate quantities hinge in our model on there being a difference in the propensities to spend of depositors and taxpayers. In the actual U.S. economy this difference likely is small and could be in either direction.

Experiment 3 . Deposit insurance payments financed by debt (Outcome 4 vs. Outcome 3). Experiment 2 shows that deposit insurance payments financed by current taxation likely would have had small real effects. Experiment 3 will show that the actual financing of deposit insurance payments with debt could have had significant real effects.

Outcome 4 differs from outcome 3 only in the manner in which deposit insurance payments are financed. Outcome 4 begins with the monetary authority tightening and private debtors defaulting in time 1 , as in outcomes 2 and 3 . In outcome 4 , however, taxes are left at their baseline 
levels. To finance insurance payments, the fiscal authority issues bonds. Consistent with its policy of tightening in period 1 , the monetary authority absorbs none of this new issue of bonds, thus forcing an endogenous further rise in the bond-money ratio at time 1.

This form of financing has sizable effects on some economic aggregates. The additional bond issue pushes worldwide real interest rates up by 53 basis points compared to the levels associated with tax-financed insurance (outcome 3). The first period trade deficit under bond-financed insurance is about 0.38 percent of GNP, as opposed to 0.31 percent under tax-financed insurance. In today's economy, this implies about a further $\$ 4$ billion increase in the annual trade deficit during period 1. The future inflation effects of bond financing are even stronger. The rate of increase in U.S. prices from period 1 to 2 jumps from 18.4 under tax-financed insurance to 23.4 under bondfinanced insurance. This difference persists for the indefinite future as well.

The explanation for all of these effects parallels that given for the effects of experiment 2 , which also involved an increase in the bond-money ratio. By the same token, the effects on aggregate variables not explicitly discussed here, such as ROW variables, are qualitatively like those in experiment 2. This is not surprising, since what we have here is a further increase in the U.S. government bond to money ratio.

Welfare effects of experiment 3 versus experiment 2 can also be explained mostly by reapplying the explanations offered after experiment 1 , so we will just summarize the magnitude of the effects. The initial old savers are about 0.2 percent better off with bond-financed as opposed to tax-financed insurance. Initial old borrowers are about 0.1 percent worse off. In the ROW, initial old savers are about 0.1 percent worse off and initial old borrowers are about 0.2 percent better off. Among the young in the U.S., bond instead of tax financing makes savers better off by from 0.9 percent in time 1 (when tax hikes are imposed in experiment 3 ) to about 0.4 percent in the long run. Borrowers born at time 1 are about 0.2 percent better off, because they aren't taxed. Subsequent 
generations of borrowers are worse off by about 0.5 percent. In the ROW, savers born at time 1 and beyond are about 0.2 to 0.5 percent better off than when the U.S. finances deposit insurance with taxes, while borrowers are 0.2 to 0.5 percent worse off.

\section{Conclusion}

Our analysis suggests that economic effects stemming from the transfer component of deposit insurance payments could be nontrivial. Some small effects probably would have been present even if the payments were financed by current taxation. The decision to finance the payments by debt, however, could have had significant real effects. 


\section{Footnotes}

${ }^{1}$ Congressional Budget Office (CBO) 1992, p. 13.

${ }^{2}$ See, for example, Modigliani-Miller (1958) and Wallace (1981). Wallace applies the Modigliani-Miller theorem to government finance.

${ }^{3} \mathrm{CBO}$ (1992) and Meltzer (1992). We find these discussions hard to interpret, in part because when they claim the transfers don't matter, they fail to answer the question "Compared to what?"

${ }^{4}$ Stockman and Tesar (1990) conclude that nontraded goods are crucial in the explanation of international business cycle facts with real business cycle models.

${ }^{5}$ Our approach also is similar to that of Altig-Carlstrom (1991) who use a stochastic version of the AK model.

${ }^{6}$ The latter assumption amounts to a hypothetical exercise in which the resource allocation and incentive effects of the deposit insurance system remain unchanged, even though no deposit insurance payments actually are made. The assumption allows us to focus on the transfer and financing aspects of the deposit insurance program. Obviously, if the government really were to renege on its obligations, people's behavior would change.

${ }^{7}$ We allow $\tau_{\mathrm{S}}$ or $\tau_{\mathrm{F}}$ to be negative in which case the government is making a real transfer. All fiscal variables are indexed by date; the $\tau$ 's can also depend on whether the taxed agent is old or young.

${ }^{8}$ In the period from 1979-80 to 1985-86, a measure of $\beta$ in the U.S. rose from about 3 to 6 . The common view is that this was a result of loose fiscal policy coupled with tight monetary policy. Here we focus primarily on monetary tightness. Our experiments begin with an open market sale that raises $\beta$ and pushes the price level at time 1 below the level that would have prevailed absent the open market sale. In the experiment with default and bond-financed deposit insurance, $\beta$ rises 
further when the monetary authority at time 1 refuses to accommodate the sale of bonds to finance the bailout. (I.e., the central bank holds money at time 1 fixed at the post-open-market sale level regardless of whether deposit insurance is bond financed or not.) Whatever $\beta$ ends up to be in time 1 , this level of $\beta$ is then maintained at time 2 and beyond.

What we have in mind is that there is an asset like land in the background and that its price drops due to an unexpected one-time shift in policy. An open market sale in our model has that type of deflationary effect, as it lowers the price level and increases the real debt burden of borrowers.

${ }^{9}$ Setting the replacement ratio at one-fourth is arbitrary, but it does not affect the qualitative results. It was chosen to match our assumption for the quantitative experiments.

${ }^{10}$ These assumptions take a huge leap of faith. Over the period 1981 to $1986 \beta$ rose from about 3 to 6 . Real interest rates jumped immediately, the dollar exchange rate climbed until 1985, and U.S. inflation dropped sharply in 1981 and 1982 . We interpret these outcomes as solely the first-period outcomes of an increase in $\beta$. We assume $\beta$ increases from 3.0 to 4.0 in the initial period, where we take a period to be roughly one year.

${ }^{11}$ Stockman-Tesar (1990) estimate that the share of tradeable goods in GDP is close to 50 percent in the U.S. and in foreign countries (see their Table 7).

${ }^{12}$ The results of the sensitivity analysis are available from the authors.

${ }^{13}$ This experiment is basically the same as the open-market sale experiment analyzed in detail by Miller-Todd (1992). Although we now allow default, that only affects the distribution of consumption between the current old in the U.S., as we explain below.

${ }^{14}$ In Miller-Todd (1992) we indicate that relative prices, and hence real exchange rates, move too little in our model following a policy change, and we argue that result likely is due to the model's demand functions for goods being too price elastic. We also argue, however, that the model's normative implications may not change much if we reformulate preferences to make 
demands more elastic, because even in the current model a relatively small change in prices causes a relatively big change in utility. 


\section{References}

Altig, David, and Carlstrom, Charles T. 1991. Inflation, personal taxes, and real output: A dynamic analysis. Journal of Money, Credit, and Banking 23: 547-71.

Auerbach, Alan J., and Kotlikoff, Laurence J. 1987. Dynamic fiscal policy. Cambridge, MA: Cambridge University Press.

Congressional Budget Office (CBO). 1992. The economic effects of the savings of loan crisis.

Washington, D.C.: U.S. Government Printing Office (January).

Meltzer, Allan H. 1992. Worry about under-investment, not deficits. Wall Street Journal A14, (March 17).

Miller, Preston J., and Todd, Richard M. 1992. Real effects of monetary policy in a world economy. Research Department Staff Report 154, Federal Reserve Bank of Minneapolis, (April).

Modigliani, Franco, and Miller, Merton H. 1958. The cost of capital, corporation finance and the theory of investment. American Economic Review 48: 261 97.

Stockman, Alan C., and Tesar, Linda L. 1990. Tastes and technology in a two-country model of the business cycle: Explaining international comovements. National Bureau of Economic Research Working Paper 3566 (December).

Wallace, Neil. 1981. A Modigliani-Miller theorem for open-market operations. American Economic Review 71: 267-74. 


\section{Table 1:}

\section{Policy Experiment Design}

\begin{tabular}{||lll||}
\hline Experiment & $\begin{array}{l}\text { Compares the outcomes } \\
\text { for assumptions sets }\end{array}$ & Assesses the impact of \\
\hline 1 & 1 and 2 & $\begin{array}{l}\text { Tightening monetary policy when there is } \\
\text { private debt default and there are no } \\
\text { deposit insurance payments. }\end{array}$ \\
2 & 2 and 3 & $\begin{array}{l}\text { Making deposit insurance payments } \\
\text { financed by current taxation. }\end{array}$ \\
3 & 3 and 4 & $\begin{array}{l}\text { Making deposit insurance payments } \\
\text { financed by debt instead of taxation. }\end{array}$ \\
\hline
\end{tabular}


Table 2:

A. PARAMETER SETTINGS COMMON TO ALL OUTCOMES

1. In U.S. and ROW

Rate of Time Preference

$\left(\delta, \delta^{*}\right)$

Preferences for Services vs. Food

$(\theta /(1-\theta)$,
$\left.\theta^{*} /\left(1-\theta^{*}\right)\right)$

1.00

Initial Bond-Money Ratio

$\left(\beta(0), \beta^{*}(0)\right)$

3.00

Reserve Requirements

$\left(\lambda, \lambda^{*}\right)$

Endowment of Services

$\left(w^{S}(1), w^{S *}(1)\right)$

99.00

First-Period Endowment of Food

$\left(w^{\mathrm{P}}(1), \mathrm{w}^{\mathrm{P} *}(1)\right)$

19.00

Second-Period Endowment of Food

$\left(w^{P}(2), w^{P *}(2)\right)$

80.00

Government Consumption of Services

$$
\left(\mathrm{g}^{\mathrm{S}}, \mathrm{g}^{\mathrm{S} *}\right)
$$

Government Consumption of Food $\left(\mathrm{g}^{\mathrm{P}}, \mathrm{g}^{\mathrm{P} *}\right)$

Initial Lump-Sum Taxes

$\left(\tau_{\mathrm{S}}(0), \tau_{\mathrm{F}}(0)\right.$,

Lump-Sum Taxes After Time 1 $\left.\tau_{S}^{*}(0), \tau_{F}^{*}(0)\right)$

$\left(\tau_{\mathrm{S}}(2), \tau_{\mathrm{F}}(2)\right.$,

2. In ROW Only

Subsequent Bond-Money Ratios

$$
\left(\beta^{*}(1), \beta^{*}(2), \ldots\right)
$$

Lump-Sum Taxes at Time 1

$\left(\tau_{\mathrm{S}}^{*}(1), \tau_{\mathrm{P}}^{*}(1)\right)$

B. U.S. PARAMETER SETTINGS AND POLICIES THAT VARY BY OUTCOMES

\begin{tabular}{|lcccc|} 
& \multicolumn{4}{c|}{ Outcomes } \\
\cline { 2 - 5 } Policies and Parameters & 1 & 2 & 3 & 4 \\
\hline Subsequent Bond-Money & 3.00 & 3.63 & 3.66 & 4.00 \\
Ratios $(\beta(1), \beta(2), \ldots)$ & & & & \\
Lump Sum Taxes at Time 1 & .00 & .00 & .30 & .00 \\
Government Payments to Old Savers at Time 1 & .00 & .00 & .60 & .64 \\
\hline
\end{tabular}


Table 3:

Effects of Policy on Prices and Quantities

\begin{tabular}{|c|c|c|c|c|}
\hline \multirow{2}{*}{$\begin{array}{l}\text { Variables \& } \\
\text { Time Periods }\end{array}$} & \multicolumn{4}{|c|}{ Outcomes } \\
\hline & 1 & 2 & 3 & 4 \\
\hline \multicolumn{5}{|c|}{ WORLD REAL INTEREST RATES (percent) } \\
\hline time $=1$ & .76 & 2.48 & 2.79 & 3.32 \\
\hline time $=2$ & .76 & 2.47 & 2.47 & 3.30 \\
\hline time $=3$ & .76 & 2.47 & 2.47 & 3.30 \\
\hline time $=\infty$ & .76 & 2.47 & 2.47 & 3.30 \\
\hline \multicolumn{5}{|c|}{ U.S. INFLATION, FOOD AND SERVICES (percent) } \\
\hline time 0 to 1 & 8.85 & 1.04 & 1.30 & .92 \\
\hline time 1 to 2 & 8.85 & 17.57 & 18.04 & 23.00 \\
\hline time 2 to 3 & 8.85 & 16.06 & 15.80 & 20.43 \\
\hline time 3 to 4 & 8.85 & 15.70 & 15.65 & 19.83 \\
\hline time $\infty$ & 8.85 & 15.59 & 15.60 & 19.64 \\
\hline \multicolumn{5}{|c|}{ ROW INFLATION, FOOD AND SERVICES (percent) } \\
\hline time 0 to 1 & 8.85 & 9.14 & 9.19 & 9.28 \\
\hline time 1 to 2 & 8.85 & 13.01 & 13.41 & 15.15 \\
\hline time 2 to 3 & 8.85 & 14.29 & 14.53 & 17.13 \\
\hline time 3 to 4 & 8.85 & 14.60 & 14.66 & 17.61 \\
\hline time $\infty$ & 8.85 & 14.70 & 14.70 & 17.76 \\
\hline \multicolumn{5}{|c|}{ U.S. NOMINAL INTEREST RATES (percent) } \\
\hline$t=1$ & 9.67 & 20.73 & 21.68 & 27.47 \\
\hline $\mathrm{t}=2$ & 9.67 & 18.99 & 18.68 & 24.50 \\
\hline $\mathrm{t}=3$ & 9.67 & 18.58 & 18.51 & 23.80 \\
\hline $\mathbf{t}=\infty$ & 9.67 & 18.45 & 18.45 & 23.59 \\
\hline
\end{tabular}


(Table 3 continued)

\begin{tabular}{|c|c|c|c|c|}
\hline \multirow{2}{*}{$\begin{array}{l}\text { Variables \& } \\
\text { Time Periods }\end{array}$} & \multicolumn{4}{|c|}{ Outcomes } \\
\hline & 1 & 2 & 3 & 4 \\
\hline \multicolumn{5}{|c|}{ ROW NOMINAL INTEREST RATES (percent) } \\
\hline $\mathrm{t}=1$ & 9.67 & 15.58 & 16.24 & 18.61 \\
\hline $\mathrm{t}=2$ & 9.67 & 17.06 & 17.33 & 20.91 \\
\hline $\mathrm{t}=3$ & 9.67 & 17.42 & 17.49 & 21.47 \\
\hline$t=\infty$ & 9.67 & 17.53 & 17.53 & 21.65 \\
\hline \multicolumn{5}{|c|}{ U.S. REAL RETURN ON SAVINGS (percent) } \\
\hline$t=1$ & -.13 & 1.10 & 1.70 & 1.35 \\
\hline$t=2$ & -.13 & .98 & 1.52 & .96 \\
\hline $\mathrm{t}=\mathbf{3}$ & -.13 & .95 & 1.47 & .94 \\
\hline $\mathrm{t}=\infty$ & -.13 & .94 & 1.46 & .94 \\
\hline \multicolumn{5}{|c|}{ ROW REAL RETURN ON SAVINGS (percent) } \\
\hline $\mathrm{t}=1$ & -.13 & .72 & .96 & 1.09 \\
\hline $\mathrm{t}=2$ & -.13 & .84 & .86 & 1.27 \\
\hline$t=3$ & -.13 & .86 & .87 & 1.31 \\
\hline$t=\infty$ & -.13 & .87 & .87 & 1.33 \\
\hline \multicolumn{5}{|c|}{ U.S. RELATIVE PRICE OF SERVICES TO FOOD } \\
\hline $\mathrm{t}=1$ & 1.0000 & 1.0052 & 1.0061 & 1.0077 \\
\hline$t=2$ & 1.0000 & 1.0011 & 1.0004 & 1.0016 \\
\hline$t=3$ & 1.0000 & 1.0001 & 1.0000 & 1.0001 \\
\hline $\mathrm{t}=\infty$ & 1.0000 & .9998 & .9998 & .9997 \\
\hline
\end{tabular}


(Table 3 continued)

\begin{tabular}{|c|c|c|c|c|}
\hline \multirow{2}{*}{$\begin{array}{l}\text { Variables \& } \\
\text { Time Periods }\end{array}$} & \multicolumn{4}{|c|}{ Outcomes } \\
\hline & 1 & 2 & 3 & 4 \\
\hline \multicolumn{5}{|c|}{ ROW RELATIVE PRICE OF SERVICES TO FOOD } \\
\hline$t=1$ & 1.0000 & .9948 & .9939 & .9923 \\
\hline $\mathrm{t}=2$ & 1.0000 & 9989 & .9996 & .9984 \\
\hline$t=3$ & 1.0000 & 9999 & 1.0000 & .9999 \\
\hline$t=\infty$ & 1.0000 & 1.0002 & 1.0002 & 1.0003 \\
\hline \multicolumn{5}{|c|}{ REAL EXCHANGE VALUE OF THE DOLLAR } \\
\hline$t=1$ & 1.0000 & 1.0052 & 1.0061 & 1.0077 \\
\hline$t=2$ & 1.0000 & 1.0011 & 1.0004 & 1.0016 \\
\hline$t=3$ & 1.0000 & 1.0001 & 1.0000 & 1.0001 \\
\hline$t=\infty$ & 1.0000 & .9998 & .9998 & .9997 \\
\hline \multicolumn{5}{|c|}{ U.S. FOREIGN TRADE SURPLUS ( $\%$ of U.S. Aggregate Endowment) } \\
\hline $\mathrm{t}=1$ & .0000 & -.2596 & -.3058 & -.3834 \\
\hline$t=2$ & .0000 & -.0556 & -.0186 & -.0788 \\
\hline$t=3$ & .0000 & -.0068 & +.0020 & -.0061 \\
\hline $\mathrm{t}=\infty$ & .0000 & +.0084 & +.0084 & +.0166 \\
\hline \multicolumn{5}{|c|}{$\begin{array}{l}\text { TOTAL U.S. LOAN DEFAULTS \& GOVERNMENT AID AT TIME } 1 \\
\text { (\% of U.S. Aggregate Endowment) }\end{array}$} \\
\hline Defaults & .00 & 1.25 & 1.22 & 1.29 \\
\hline Aid to Old Savers & .00 & .00 & .30 & .32 \\
\hline
\end{tabular}


Table 4: Effects of Policy on Agents' Welfare

$(-1$ times percentage change in wealth required to bring agent's welfare back to its baseline level)

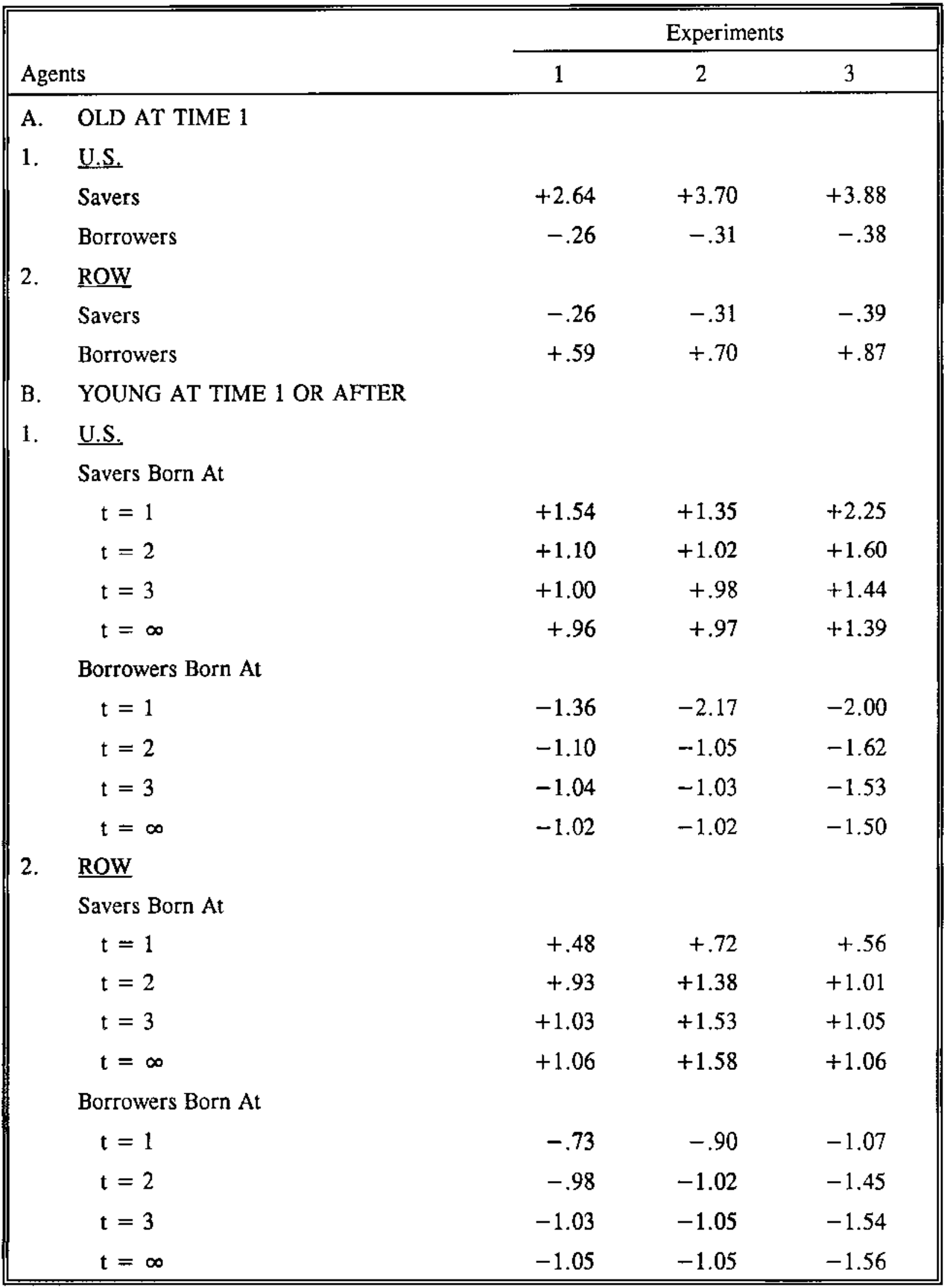

